\title{
The near UV absorption cross-sections and the rate coefficients for the ozonolysis of a series of styrene-like compounds
}

\author{
A. Le Person ${ }^{\mathrm{a}}$, G. Eyglunent ${ }^{\mathrm{a}}$, V. Daële ${ }^{\mathrm{a}}$, \\ A. Mellouki ${ }^{a, *}$, Y. Mu ${ }^{b}$ \\ a ICARE-CNRS, 1C Avenue de la Recherche Scientifique, 45071 Orléans Cedex 02, France \\ ${ }^{\mathrm{b}}$ Research Center for Eco-Environmental Sciences, \\ Chinese Academy of Sciences, Beijing 100085, China
}

Received 12 July 2007; received in revised form 28 August 2007; accepted 3 September 2007

Available online 8 September 2007

\begin{abstract}
The UV absorption cross-sections and the rate coefficients for the ozonolysis of styrene, $\alpha$-methylstyrene, $\beta$-methylstyrene, 2 -methylstyrene and indene have been investigated. The absorption spectra were measured using a diode array spectrometer over the wavelength range $260-310 \mathrm{~nm}$ at $328 \mathrm{~K}$. Large absorption cross-sections $\left(\sim 10^{-18} \mathrm{~cm}^{2}\right.$ molecule $\left.\mathrm{e}^{-1}\right)$ were observed for the investigated compounds over the wavelength range $260-280 \mathrm{~nm}$, while their absorption cross-sections decreased sharply above $290 \mathrm{~nm}$ with values of about $10^{-20}$ to $10^{-21} \mathrm{~cm}^{2}$ molecule $\mathrm{m}^{-1}$ around $310 \mathrm{~nm}$. The rate coefficients for the reactions of the aromatic compounds studied and $\mathrm{O}_{3}$ measured in a simulation chamber using both absolute and relative methods at $295 \pm 3 \mathrm{~K}$ and atmospheric pressure were (in $10^{-17} \mathrm{~cm}^{3}$ molecule $\left.{ }^{-1} \mathrm{~s}^{-1}\right):(1.5 \pm 0.3),(1.8 \pm 0.4)$, (3.1 \pm 0.6$)$ and (16 \pm 4 ) for styrene, $\alpha$-methylstyrene, 2-methylstyrene and indene, respectively. The data obtained were used to estimate the lifetimes of the investigated compounds.
\end{abstract}

(C) 2007 Elsevier B.V. All rights reserved.

Keywords: Aromatics; Styrene; Absorption cross-section; Ozonolysis; Kinetic

\section{Introduction}

Aromatic compounds such as styrene and similar molecules structure can be emitted into the atmosphere from different sources: solvents, combustion, buildings materials, adhesives [1-3]. In addition to their harmful human health effects, in a similar manner to other aromatics, they play an important role in urban air pollution and are important precursors for secondary organic aerosol formation [4]. Once in the atmosphere, they can be degraded by photolysis and/or by oxidation via gas phase reactions with $\mathrm{OH}$ and $\mathrm{NO}_{3}$ radicals and ozone. In order to evaluate their atmospheric impacts, the UV absorption cross-sections and chemical kinetics data of these possible loss processes are required. In this work, we have determined the UV spectra of a series of aromatics (styrene, 2-methylstyrene, $\alpha$-methylstyrene, $\beta$-methylstyrene

\footnotetext{
* Corresponding author. Tel.: +332 382576 12; fax: +3323825 5079 .

E-mail address: mellouki@cnrs-orleans.fr (A. Mellouki).
}

and indene) as well as the rate coefficients for their reactions with ozone:

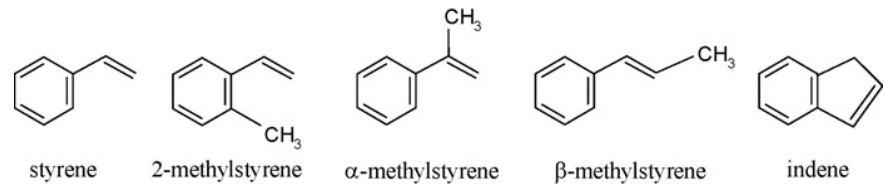

To the best of our knowledge, there is still no available data on the photolysis of these compounds and only few data exist on the ozonolysis of styrene and indene [5-8]. The available data on the $\mathrm{OH}$ reaction with some of these species indicate that this process is quite fast, the rate coefficients being $k_{\mathrm{OH}}=(5-7.8) \times 10^{-11} \mathrm{~cm}^{3}$ molecule $\mathrm{s}^{-1} \mathrm{~s}^{-1}$ [8-10]. Therefore, in order to evaluate the atmospheric importance of other loss processes (photolysis and ozonolysis) we have measured their UV absorption cross-sections and the rate coefficients for their ozonolysis. Hence, this enables us to discuss the atmospheric importance of different processes. 


\section{Experimental}

\subsection{UV absorption cross-sections}

The setup and the methodology used for data analysis have been described in detail previously [11] and are briefly presented here. Absorption measurements were made using a UV-vis spectrophotometer (Chromex 250IS) equipped with a 1800 grooves/mm grating and a 1024 element diode array detector (Princeton Instrument, Inc.). The collimated output of a $30 \mathrm{~W}$ $\mathrm{D}_{2}$ lamp was passed through a $100 \mathrm{~cm}$ long double-jacketed Pyrex cell with inner diameter of $2.5 \mathrm{~cm}$ and focused onto the entrance slit of the spectrometer.

The absorption measurements were performed under static and dynamic conditions over the wavelength range $260-360 \mathrm{~nm}$ with four central wavelengths $(250,280,310$, and $340 \mathrm{~nm})$, three overlaps (about $10 \mathrm{~nm}$ for each overlap) and with a resolution between 0.2 and $1 \mathrm{~nm}$. In order to reduce the possible photodecomposition of the investigated compounds at short wavelengths a BK7 filter was used to cut off the UV light below $260 \mathrm{~nm}$. This filter was placed between the $\mathrm{D}_{2}$ lamp and the absorption cell.

The investigated aromatics have relatively low vapour pressures (about 0.8 Torr at $20^{\circ} \mathrm{C}$ ). To avoid adsorptions of the aromatics on the walls, the temperature of the cell was maintained at $328 \mathrm{~K}$. A $0-10$ Torr manometer was used for pressure measurements. The typical pressure ranges of each compound were set from 0.1 to 0.9 Torr.

Absorption cross-sections were derived using the BeerLambert's law:

$\sigma(l)=\ln \frac{\left[\left(I_{0}(\lambda) / I(\lambda)\right]\right.}{L \times C}$

where $\sigma(\lambda)$ is the absorption cross-section $\left(\mathrm{cm}^{2}\right.$ molecule $\left.{ }^{-1}\right)$ at wavelength $\lambda, L$ the path length in $\mathrm{cm}$ and $C$ is the concentration in molecule $\mathrm{cm}^{-3}$. $I$ and $I_{0}$ are, respectively, the light intensities with and without the aromatic compounds in the absorption cell. Each measurement of $I$ and $I_{0}$ consisted of 10-20 scans of the diode array and required at a maximum of $1 \mathrm{~s}$ to complete. The reference spectrum $I_{0}$ was recorded after purging the absorption cell with He. For each compound, the absorption cross-sections were measured by two methods. In the static method, measurements were conducted when the absorption cell was filled with a fixed concentration of the aromatic compounds, while in the dynamic method a fixed pressure of the aromatic compound was flowed through the absorption cell. For each $40 \mathrm{~nm}$ region of the spectrum, absorption measurements were made at 12 different pressures, including 6 static and 6 dynamic determinations. $I_{0}$ was recorded before and after each $I$ measurement.

\subsection{Rate coefficients for ozonolysis}

The kinetics investigations of the reactions of ozone with the aromatic series of compounds were carried out in a $7.3 \mathrm{~m}^{3}$ chamber fabricated from Teflon at $295 \pm 3 \mathrm{~K}$ and 760 Torr total pressure of air, using both absolute and relative rate methods. Reactants were introduced into the chamber via a stream of purified air. The initial concentrations of the aromatics and reference compounds were calculated from the amount (the volume or the pressure) introduced. Ozone was produced either by $\mathrm{O}_{2}$ photolysis via a $\mathrm{Hg}$ lamp or by passing $\mathrm{O}_{2}$ through an electrical discharge before entering the chamber. A fan made of Teflon inside the chamber ensured rapid mixing of the reaction mixture within less than $1 \mathrm{~min}$.

A White mirror system installed inside the chamber and aligned with an optical path length of $166 \mathrm{~m}$ was used for in situ concentration measurements by Fourier Transform Infrared (FTIR) spectroscopy (Nicolet, Magna 5700). Infrared spectra were derived from the co-addition of 30-100 scans, collected over 70-220 min period and recorded using a resolution of $1 \mathrm{~cm}^{-1}$. For absolute kinetic experiments, ozone concentrations were monitored by an UV absorption analyzer (HORIBA, APOA-360) and by FTIR spectroscopy while for relative rate measurements, the concentrations of the aromatics, ozone and reference compounds were monitored by FTIR. The IR bands used for analysis were as follows (in $\mathrm{cm}^{-1}$ ): 750-800 (styrene, $\alpha$-methylstyrene and indene), 725-730 and 890-940 (2-methylstyrene), 980-1100 $\left(\mathrm{O}_{3}\right), 1075-1150$ (1,3-dioxolane), 912 (propene), 813 (propylvinyl ether) and 2934 (cyclohexene). The leak rate of the chamber was determined by measuring the decay of $\mathrm{SF}_{6}\left(935-954 \mathrm{~cm}^{-1}\right)$, used as a tracer, which was added at the start of the experiments. For each experiment, the gas mixture was analyzed for at least $30 \mathrm{~min}$ before adding the second reactant to estimate the leakage and wall loss.

Since $\mathrm{OH}$ radicals can be formed from the ozonolysis of organic compounds [12,13], cyclohexane, dibutyl ether or 1,3dioxolane was added into the gas mixture to scavenge or to trace the $\mathrm{OH}$ radicals formed and to establish whether or not secondary reactions involving $\mathrm{OH}$ radicals were significant under our experimental conditions.

\subsection{Chemicals}

The sources of the liquid chemicals used and their stated purity levels were as follows: styrene, $\alpha$-methylstyrene, $\beta$-methylstyrene, indene, 1,3-dioxolane, cyclohexane, cyclohexene, propylvinyl ether, dibutyl ether (Fluka, 99\%) and 2-methylstyrene (Fluka, 95\%).

\section{Results and discussion}

\subsection{UV absorption cross-sections}

Absorption spectra were measured between 260 and $360 \mathrm{~nm}$ (270-360 $\mathrm{nm}$ for indene) at (328 \pm 2$) \mathrm{K}$ and different pressures (at least 12 pressures for each compound) ranging from 0.1 to 0.9 Torr. Because the deviation was very large beyond $310 \mathrm{~nm}$ due to small absorption cross-sections, the cross-sections are reported here only between 260 and $310 \mathrm{~nm}$. Good linear relations between the absorbance and the pressure were found for all investigated aromatics, as shown in Fig. 1 at 280 and $290 \mathrm{~nm}$. The obtained spectra are shown in Fig. 1, and the cross-section values are listed in Table 1 in $1 \mathrm{~nm}$ intervals. The precision of the experimental cross-sections was calculated at each wavelength using the standard deviation for different measurements. 

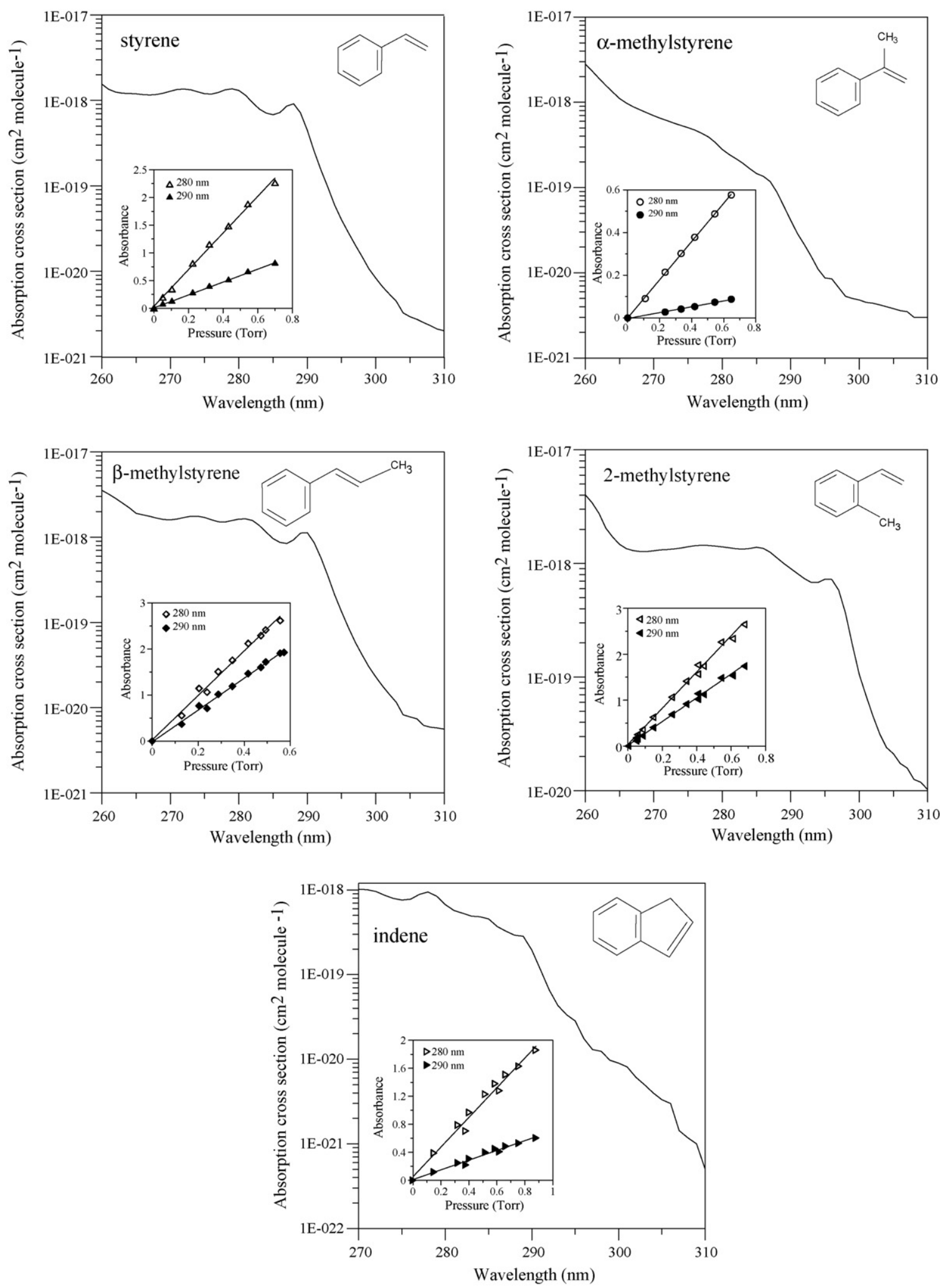

Fig. 1. UV absorption spectra and absorbance at 280 and $290 \mathrm{~nm}$ vs. the pressure in the absorption cell of styrene, $\alpha$-methylstyrene, $\beta$-methylstyrene, 2 -methylstyrene and indene at $328 \mathrm{~K}$.

In general, between 260 and $310 \mathrm{~nm}$ (270-310 nm for indene), the standard deviation of the measured absorption cross-section was better than $15 \%$. At $\lambda>310 \mathrm{~nm}$, the deviation increased to more than $20-30 \%$ due to small absorption cross-sections.
Uncertainties of 5-10\% in the measured concentrations of aromatics were added to the reported errors in the cross-sections. Other uncertainties in path length, temperature and wavelength were estimated to be less than $1 \%$. 
Table 1

Absorption cross-sections (in $\mathrm{cm}^{2}$ molecule ${ }^{-1}$ ) of styrene, 2-methylstyrene, $\alpha$ methylstyrene, $\beta$-methylstyrene and indene at $328 \mathrm{~K}$

\begin{tabular}{|c|c|c|c|c|c|}
\hline$\lambda(\mathrm{nm})$ & $\sigma_{\text {styrene }}$ & $\sigma_{2-\text { methylstyrene }}$ & $\sigma_{\alpha \text {-methylstyrene }}$ & $\sigma_{\beta \text {-methylstyrene }}$ & $\sigma_{\text {indene }}$ \\
\hline 260 & $1.6 \mathrm{E}-18$ & $4.0 \mathrm{E}-18$ & $2.8 \mathrm{E}-18$ & $3.6 \mathrm{E}-18$ & - \\
\hline 261 & $1.4 \mathrm{E}-18$ & $3.4 \mathrm{E}-18$ & $2.3 \mathrm{E}-18$ & $3.2 \mathrm{E}-18$ & - \\
\hline 262 & $1.3 \mathrm{E}-18$ & $2.8 \mathrm{E}-18$ & $1.9 \mathrm{E}-18$ & $2.9 \mathrm{E}-18$ & - \\
\hline 263 & $1.2 \mathrm{E}-18$ & $2.1 \mathrm{E}-18$ & $1.6 \mathrm{E}-18$ & $2.5 \mathrm{E}-18$ & - \\
\hline 264 & $1.2 \mathrm{E}-18$ & $1.7 \mathrm{E}-18$ & $1.3 \mathrm{E}-18$ & $2.2 \mathrm{E}-18$ & - \\
\hline 265 & $1.2 \mathrm{E}-18$ & $1.5 \mathrm{E}-18$ & $1.1 \mathrm{E}-18$ & $1.9 \mathrm{E}-18$ & - \\
\hline 266 & $1.2 \mathrm{E}-18$ & $1.4 \mathrm{E}-18$ & $9.8 \mathrm{E}-19$ & $1.8 \mathrm{E}-18$ & - \\
\hline 267 & $1.2 \mathrm{E}-18$ & $1.3 \mathrm{E}-18$ & $8.9 \mathrm{E}-19$ & $1.8 \mathrm{E}-18$ & - \\
\hline 268 & $1.2 \mathrm{E}-18$ & $1.3 \mathrm{E}-18$ & $8.2 \mathrm{E}-19$ & $1.7 \mathrm{E}-18$ & - \\
\hline 269 & $1.2 \mathrm{E}-18$ & $1.3 \mathrm{E}-18$ & $7.5 \mathrm{E}-19$ & $1.6 \mathrm{E}-18$ & - \\
\hline 270 & $1.3 \mathrm{E}-18$ & $1.3 \mathrm{E}-18$ & $7.0 \mathrm{E}-19$ & $1.6 \mathrm{E}-18$ & $9.3 \mathrm{E}-19$ \\
\hline 271 & $1.3 \mathrm{E}-18$ & $1.3 \mathrm{E}-18$ & $6.5 \mathrm{E}-19$ & $1.6 \mathrm{E}-18$ & $9.2 \mathrm{E}-19$ \\
\hline 272 & $1.4 \mathrm{E}-18$ & $1.3 \mathrm{E}-18$ & $6.1 \mathrm{E}-19$ & $1.7 \mathrm{E}-18$ & $8.8 \mathrm{E}-19$ \\
\hline 273 & $1.3 \mathrm{E}-18$ & $1.3 \mathrm{E}-18$ & $5.7 \mathrm{E}-19$ & $1.8 \mathrm{E}-18$ & $8.0 \mathrm{E}-19$ \\
\hline 274 & $1.3 \mathrm{E}-18$ & $1.4 \mathrm{E}-18$ & $5.3 \mathrm{E}-19$ & $1.8 \mathrm{E}-18$ & $7.4 \mathrm{E}-19$ \\
\hline 275 & $1.2 \mathrm{E}-18$ & $1.4 \mathrm{E}-18$ & $5.1 \mathrm{E}-19$ & $1.7 \mathrm{E}-18$ & $7.1 \mathrm{E}-19$ \\
\hline 276 & $1.2 \mathrm{E}-18$ & $1.4 \mathrm{E}-18$ & $4.7 \mathrm{E}-19$ & $1.6 \mathrm{E}-18$ & $7.2 \mathrm{E}-19$ \\
\hline 277 & $1.2 \mathrm{E}-18$ & $1.5 \mathrm{E}-18$ & $4.3 \mathrm{E}-19$ & $1.5 \mathrm{E}-18$ & $8.2 \mathrm{E}-19$ \\
\hline 278 & $1.4 \mathrm{E}-18$ & $1.4 \mathrm{E}-18$ & $3.9 \mathrm{E}-19$ & $1.5 \mathrm{E}-18$ & $8.7 \mathrm{E}-19$ \\
\hline 279 & $1.4 \mathrm{E}-18$ & $1.4 \mathrm{E}-18$ & $3.4 \mathrm{E}-19$ & $1.6 \mathrm{E}-18$ & $7.8 \mathrm{E}-19$ \\
\hline 280 & $1.3 \mathrm{E}-18$ & $1.4 \mathrm{E}-18$ & $2.8 \mathrm{E}-19$ & $1.6 \mathrm{E}-18$ & $6.3 \mathrm{E}-19$ \\
\hline 281 & $1.2 \mathrm{E}-18$ & $1.4 \mathrm{E}-18$ & $2.5 \mathrm{E}-19$ & $1.6 \mathrm{E}-18$ & $5.4 \mathrm{E}-19$ \\
\hline 282 & $9.6 \mathrm{E}-19$ & $1.4 \mathrm{E}-18$ & $2.2 \mathrm{E}-19$ & $1.6 \mathrm{E}-18$ & $5.0 \mathrm{E}-19$ \\
\hline 283 & $8.1 \mathrm{E}-19$ & $1.3 \mathrm{E}-18$ & $1.9 \mathrm{E}-19$ & $1.4 \mathrm{E}-18$ & $4.6 \mathrm{E}-19$ \\
\hline 284 & $7.3 \mathrm{E}-19$ & $1.3 \mathrm{E}-18$ & $1.7 \mathrm{E}-19$ & $1.1 \mathrm{E}-18$ & $4.5 \mathrm{E}-19$ \\
\hline 285 & $7.0 \mathrm{E}-19$ & $1.4 \mathrm{E}-18$ & $1.5 \mathrm{E}-19$ & $9.7 \mathrm{E}-19$ & $4.3 \mathrm{E}-19$ \\
\hline 286 & $7.3 \mathrm{E}-19$ & $1.4 \mathrm{E}-18$ & $1.4 \mathrm{E}-19$ & $8.7 \mathrm{E}-19$ & $3.5 \mathrm{E}-19$ \\
\hline 287 & $8.6 \mathrm{E}-19$ & $1.3 \mathrm{E}-18$ & $1.2 \mathrm{E}-19$ & $8.4 \mathrm{E}-19$ & $2.6 \mathrm{E}-19$ \\
\hline 288 & $9.3 \mathrm{E}-19$ & $1.1 \mathrm{E}-18$ & $8.8 \mathrm{E}-20$ & $9.3 \mathrm{E}-19$ & $2.7 \mathrm{E}-19$ \\
\hline 289 & $7.6 \mathrm{E}-19$ & $10.0 \mathrm{E}-19$ & $6.0 \mathrm{E}-20$ & $1.1 \mathrm{E}-18$ & $2.7 \mathrm{E}-19$ \\
\hline 290 & $4.9 \mathrm{E}-19$ & $9.0 \mathrm{E}-19$ & $4.1 \mathrm{E}-20$ & $1.1 \mathrm{E}-18$ & $1.8 \mathrm{E}-19$ \\
\hline 291 & $2.8 \mathrm{E}-19$ & $8.1 \mathrm{E}-19$ & $2.9 \mathrm{E}-20$ & $8.6 \mathrm{E}-19$ & $1.1 \mathrm{E}-19$ \\
\hline 292 & $1.7 \mathrm{E}-19$ & $7.4 \mathrm{E}-19$ & $2.1 \mathrm{E}-20$ & $5.7 \mathrm{E}-19$ & $6.3 \mathrm{E}-20$ \\
\hline 293 & $1.1 \mathrm{E}-19$ & $6.8 \mathrm{E}-19$ & $1.6 \mathrm{E}-20$ & $3.5 \mathrm{E}-19$ & $4.0 \mathrm{E}-20$ \\
\hline 294 & $6.9 \mathrm{E}-20$ & $6.8 \mathrm{E}-19$ & $1.1 \mathrm{E}-20$ & $2.1 \mathrm{E}-19$ & $3.1 \mathrm{E}-20$ \\
\hline 295 & $4.6 \mathrm{E}-20$ & $7.3 \mathrm{E}-19$ & $8.3 \mathrm{E}-21$ & $1.3 \mathrm{E}-19$ & $2.6 \mathrm{E}-20$ \\
\hline 296 & $3.3 \mathrm{E}-20$ & $7.2 \mathrm{E}-19$ & $6.4 \mathrm{E}-21$ & $8.7 \mathrm{E}-20$ & $1.5 \mathrm{E}-20$ \\
\hline 297 & $2.3 \mathrm{E}-20$ & $5.8 \mathrm{E}-19$ & $4.9 \mathrm{E}-21$ & $5.9 \mathrm{E}-20$ & $1.5 \mathrm{E}-20$ \\
\hline 298 & $1.6 \mathrm{E}-20$ & $3.7 \mathrm{E}-19$ & $4.1 \mathrm{E}-21$ & $4.2 \mathrm{E}-20$ & $1.7 \mathrm{E}-20$ \\
\hline 299 & $1.1 \mathrm{E}-20$ & $1.9 \mathrm{E}-19$ & $3.7 \mathrm{E}-21$ & $3.0 \mathrm{E}-20$ & $1.3 \mathrm{E}-20$ \\
\hline 300 & $8.0 \mathrm{E}-21$ & $1.1 \mathrm{E}-19$ & $4.4 \mathrm{E}-21$ & $2.3 \mathrm{E}-20$ & $9.0 \mathrm{E}-21$ \\
\hline 301 & $5.6 \mathrm{E}-21$ & $6.9 \mathrm{E}-20$ & $4.3 \mathrm{E}-21$ & $1.8 \mathrm{E}-20$ & $8.1 \mathrm{E}-21$ \\
\hline 302 & $4.0 \mathrm{E}-21$ & $4.5 \mathrm{E}-20$ & $4.4 \mathrm{E}-21$ & $1.4 \mathrm{E}-20$ & $6.1 \mathrm{E}-21$ \\
\hline 303 & $2.9 \mathrm{E}-21$ & $3.2 \mathrm{E}-20$ & $4.3 \mathrm{E}-21$ & $1.2 \mathrm{E}-20$ & $5.0 \mathrm{E}-21$ \\
\hline 304 & $2.3 \mathrm{E}-21$ & $2.4 \mathrm{E}-20$ & $2.8 \mathrm{E}-21$ & $7.3 \mathrm{E}-21$ & $4.0 \mathrm{E}-21$ \\
\hline 305 & $1.8 \mathrm{E}-21$ & $2.1 \mathrm{E}-20$ & $2.8 \mathrm{E}-21$ & $6.3 \mathrm{E}-21$ & $3.3 \mathrm{E}-21$ \\
\hline 306 & $1.4 \mathrm{E}-21$ & $1.7 \mathrm{E}-20$ & $2.7 \mathrm{E}-21$ & $5.5 \mathrm{E}-21$ & $3.0 \mathrm{E}-21$ \\
\hline 307 & $7.0 \mathrm{E}-21$ & $1.6 \mathrm{E}-20$ & $3.8 \mathrm{E}-21$ & $8.3 \mathrm{E}-21$ & $1.4 \mathrm{E}-21$ \\
\hline 308 & $5.8 \mathrm{E}-21$ & $1.3 \mathrm{E}-20$ & $4.1 \mathrm{E}-21$ & $7.4 \mathrm{E}-21$ & $1.2 \mathrm{E}-21$ \\
\hline 309 & $4.7 \mathrm{E}-21$ & $1.2 \mathrm{E}-20$ & $4.0 \mathrm{E}-21$ & $6.8 \mathrm{E}-21$ & $1.0 \mathrm{E}-21$ \\
\hline 310 & $3.7 \mathrm{E}-21$ & $1.0 \mathrm{E}-20$ & $3.8 \mathrm{E}-21$ & $6.3 \mathrm{E}-21$ & $5.0 \mathrm{E}-22$ \\
\hline
\end{tabular}

The UV absorption cross-sections obtained by the dynamic method agree very well with those measured by the static method over the wavelengths range $260-310 \mathrm{~nm}$ with relative error less than $10 \%$. In general, the UV spectra of the investigated compounds show similar absorption characteristics. Several obvious bands for styrene, 2-methylstyrene, $\beta$-methylstyrene and indene were observed over the investigated wavelengths, but not for $\alpha$ methylstyrene. No fine structure, characteristic of $\pi$ electronic transitions is detectable under our experimental conditions. The styrene series show stronger absorption over the wavelengths range $260-280 \mathrm{~nm}$, with absorption cross-sections about $10^{-18} \mathrm{~cm}^{2}$ molecule ${ }^{-1}$, whereas above $290 \mathrm{~nm}$, their absorption decreases sharply with values less than $10^{-20} \mathrm{~cm}^{2}$ molecule ${ }^{-1}$ around $310 \mathrm{~nm}$. An obvious absorption peak around $290 \mathrm{~nm}$ was observed for styrene while the absorption peaks for 2 -methylstyrene and $\beta$-methylstyrene shift towards longer wavelengths. The bathochromic shift by an ortho-substitution of a methyl group is comparable to that of benzene/toluene [14] or benzaldehyde/o-tolualdehyde [15]. However, the opposite effect (hypsochromic shift) occurs for $\alpha$-methylstyrene and indene compared to styrene.

The absorption cross-sections from this study were used to calculate the photodissociation rate constants $(J)$ for the aromatic series by using the following relationship:

$J=\int_{\lambda} \sigma(\lambda) \Phi(\lambda) I(\lambda) \mathrm{d} \lambda$

where $\sigma(\lambda), \Phi(\lambda)$ and $I(\lambda)$ are the absorption cross-section $\left(\mathrm{cm}^{2}\right.$ molecule $\left.{ }^{-1}\right)$, the primary photolysis quantum yield (molecule photon ${ }^{-1}$ ) and the actinic flux (photon $\mathrm{cm}^{-2} \mathrm{~s}^{-1}$ ) of solar radiation at the wavelength $\lambda$, respectively.

The procedure for calculating $J$ was identical to that of previous studies [16,17]. The calculations were carried out under a representative set of atmospheric conditions (at 12:00 on 1st June, cloudless and at sea level and a latitude of $30^{\circ} \mathrm{N}$ ). The data for the actinic flux at the Earth's surface and zenith angle $\left(\theta=10^{\circ}\right.$ for 1st June at 12:00) are taken from Finlayson-Pitts and Pitts [18]. Because no data on the primary quantum yields are available for the investigated aromatics, only the upper limits for $J$ are calculated by assuming $\Phi(\lambda)=1$ at all wavelengths. Using the data obtained here and assuming that the cross-sections above $320 \mathrm{~nm}$ up to $360 \mathrm{~nm}$ to be in the order of the cross-section at $320 \mathrm{~nm}, \sim 10^{-21} \mathrm{~cm}^{2}$ molecule ${ }^{-1}$, we estimated the upper limits for the $J$ values of the studied species (in $10^{-6} \mathrm{~s}^{-1}$ ): 7, 7, 9, 10 and 1 for styrene, $\alpha$-methylstyrene, $\beta$-methylstyrene, 2 methylstyrene and indene, respectively. The contribution to the photolysis for wavelength higher than $360 \mathrm{~nm}$ is considered as negligible as for other aromatic compounds [14].

\subsection{Rate coefficients for ozonolysis}

\subsubsection{Absolute method}

The reaction rate coefficients were determined by monitoring the $\mathrm{O}_{3}$ concentration in the presence of known concentrations of the aromatics in large excess. In our experimental conditions, $\mathrm{O}_{3}$ is lost through the following reactions:

$\mathrm{O}_{3} \rightarrow$ wall loss and leak $k_{\mathrm{w}}$

$\mathrm{O}_{3}+$ aromatic $\rightarrow$ products $k_{\mathrm{ar}}$

where $k_{\mathrm{w}}$ represents the first-order leak and wall loss rates of ozone while $k_{\text {ar }}$ is the reaction rate coefficient of the ozone with the aromatics to be measured. The initial concentrations were in the ranges $70-310 \mathrm{ppbv}$ and $0.6-5.2 \mathrm{ppmv}$ for ozone and the aromatics, respectively. The concentrations of aromatics were in 
all cases at least 8 times higher than those of $\mathrm{O}_{3}$. The observed decay of ozone was given by the expression:

$\frac{-\mathrm{d}\left[\mathrm{O}_{3}\right]}{\mathrm{d} t}=k_{\mathrm{ar}}[$ Aromatic $]\left[\mathrm{O}_{3}\right]+k_{\mathrm{w}}\left[\mathrm{O}_{3}\right]$

Ozonolysis rate coefficients $k_{\mathrm{ar}}$ are thus derived from the following equation:

$\ln \left(\frac{\left[\mathrm{O}_{3}\right]_{0}}{\left[\mathrm{O}_{3}\right]_{t}}\right)=k_{\mathrm{tot}} \times t$

where

$k_{\mathrm{tot}}=k^{\prime}+k_{\mathrm{w}} \quad$ and $\quad k^{\prime}=k_{\mathrm{ar}}[$ Aromatic $]$

Hence, the rate coefficients for the ozonolysis of the aromatics can be derived from the decay of ozone measured by the UV analyzer and in some runs also checked by FTIR. The ozone analyzer showed a slight response to the aromatics since these species have an important absorption at $254 \mathrm{~nm}$ (i.e. $\sigma \approx 10^{-18} \mathrm{~cm}^{2}$ molecule ${ }^{-1}$ ), ozone being monitored at this wavelength. The additional signal due to aromatics becomes constant after 5-10 min and depends on their initial concentration. Consequently, only data obtained after this stabilization time are used to derive the reactions rate coefficients.

The experimental conditions and the results for $k_{\mathrm{w}}$ and $k^{\prime}$ are listed in Table 2 and an example of the typical plots according to Eq. (4) is shown in Fig. 2. The leak rate constant derived from the loss of $\mathrm{SF}_{6}$ was found to be about $2 \times 10^{-5} \mathrm{~s}^{-1}$ and the loss of ozone due to leak and wall adsorption was calculated from its decay before the introduction of the aromatic compound and is $3-9 \times 10^{-5} \mathrm{~s}^{-1}$. When ozone was added after the aromatic, $k_{\mathrm{w}}$ was assumed to be $4 \times 10^{-5} \mathrm{~s}^{-1}$. The ozone decay rates $k_{\text {tot }}$ measured in the presence of the aromatic compound were used to calculate the decay $k^{\prime}=\left(k_{\mathrm{tot}}-k_{\mathrm{w}}\right)$ due to the ozonolysis. Ozone concentrations monitored by FTIR spectroscopy were found to be in good agreement with those monitored by the analyzer, as illustrated in Fig. 2c for the mixture of 2-methylstyrene and ozone. Experiments where ozone was injected in the chamber before the aromatics are also in accordance with those conducted the other way (ozone was introduced after the aromatics). Fig. 3 presents the linear plots of $k^{\prime}$ versus the concentration of each aromatic compound and the slopes are equal to the ozonolysis reaction rate coefficients $k_{\text {ar }}$ given in Table 4 . The quoted errors for $k_{\mathrm{ar}}$ determined in this work include statistic uncertainties $2 \sigma$ from the least-squares analysis, the estimated systematic error $(5-10 \%)$ in the measured concentrations and the uncertainties in the time intervals.

A number of experiments have been carried out in the presence of $\mathrm{OH}$ scavenger (27 ppmv of cyclohexane or 44-65 ppmv of 1,3-dioxolane) whose reactivity towards ozone is negligible. The reaction rate coefficients of $\mathrm{OH}$ radicals with cyclohexane and 1,3-dioxolane are $k_{\text {cyclohexane }+\mathrm{OH}}=7.2 \times 10^{-12} \mathrm{~cm}^{3}$ molecule $\mathrm{s}^{-1} \mathrm{~s}^{-1} \quad[19] \quad$ and $k_{1,3-\text { dioxolane }+\mathrm{OH}}=(1.11 \pm 0.09) \times 10^{-11} \mathrm{~cm}^{3}$ molecule $^{-1} \mathrm{~s}^{-1}$

[20]. The difference between the rate coefficients obtained in the absence and in the presence of $\mathrm{OH}$ scavenger was found to be less than $20 \%$ (see Figs. 2 d or 3). Some experiments have been conducted in the presence of 1,3-dixolane $(\sim 600 \mathrm{ppbv})$
Table 2

Experimental conditions and results for the absolute kinetic studies of $\mathrm{O}_{3}$ reaction with aromatics at $295 \pm 3 \mathrm{~K}$ and atmospheric pressure $\left(k^{\prime}=k_{\mathrm{tot}}-k_{\mathrm{W}}\right)$

\begin{tabular}{|c|c|c|c|}
\hline$[\text { Aromatic }]_{0}(\mathrm{ppmv})$ & {$\left[\mathrm{O}_{3}\right]_{0}(\mathrm{ppbv})$} & $k_{\mathrm{W}}\left(10^{-5} \mathrm{~s}^{-1}\right)$ & $\overline{k^{\prime}\left(10^{-4} \mathrm{~s}^{-1}\right)}$ \\
\hline \multicolumn{4}{|l|}{ Styrene } \\
\hline $1.1^{\mathrm{a}}$ & 137 & $7.5 \pm 0.4$ & $4 \pm 1$ \\
\hline 1.9 & 160 & $5.1 \pm 0.1$ & $7 \pm 1$ \\
\hline 2.3 & 190 & $6.0 \pm 0.1$ & $9 \pm 1$ \\
\hline 3.2 & 177 & $5.3 \pm 0.1$ & $11 \pm 1$ \\
\hline 4.6 & 220 & $4.0 \pm 0.1$ & $18 \pm 2$ \\
\hline 5.2 & 200 & $5.7 \pm 0.1$ & $18 \pm 2$ \\
\hline \multicolumn{4}{|l|}{$\alpha$-Methylstyrene } \\
\hline 0.7 & 98 & $8.6 \pm 0.1$ & $3 \pm 1$ \\
\hline 1.0 & 91 & $4.2 \pm 0.1$ & $5 \pm 1$ \\
\hline 1.0 & 84 & $3.2 \pm 0.1$ & $5 \pm 1$ \\
\hline 1.0 & 82 & $3.7 \pm 0.1$ & $6 \pm 1$ \\
\hline 1.1 & 170 & $5.1 \pm 0.1$ & $5 \pm 1$ \\
\hline 1.3 & 138 & $9.1 \pm 0.1$ & $6 \pm 1$ \\
\hline 1.5 & 143 & $7.8 \pm 0.1$ & $7 \pm 1$ \\
\hline 2.6 & 211 & $6.0 \pm 0.1$ & $12 \pm 1$ \\
\hline 3.8 & 307 & $3.5 \pm 0.1$ & $15 \pm 2$ \\
\hline \multicolumn{4}{|l|}{ 2-Methylstyrene } \\
\hline 0.9 & 180 & $4^{\mathrm{b}}$ & $6 \pm 1$ \\
\hline $1.3^{c}$ & 180 & $4.7 \pm 0.1$ & $9 \pm 1$ \\
\hline $1.6^{\mathrm{d}}$ & 140 & $4^{\mathrm{b}}$ & $11 \pm 1$ \\
\hline 2.5 & 200 & $6.0 \pm 0.1$ & $17 \pm 2$ \\
\hline 3.5 & 320 & $3.8 \pm 0.1$ & $26 \pm 3$ \\
\hline 3.9 & 140 & $4^{b}$ & $32 \pm 4$ \\
\hline 4.3 & 140 & $4^{\mathrm{b}}$ & $34 \pm 4$ \\
\hline 5.2 & 190 & $4^{b}$ & $38 \pm 5$ \\
\hline \multicolumn{4}{|l|}{ Indene } \\
\hline $0.6^{\mathrm{d}}$ & 75 & $4^{\mathrm{b}}$ & $25 \pm 3$ \\
\hline $0.8^{\mathrm{e}}$ & 96 & $4^{\mathrm{b}}$ & $28 \pm 3$ \\
\hline 0.8 & 47 & $4^{\mathrm{b}}$ & $30 \pm 3$ \\
\hline 1.0 & 100 & $4^{\mathrm{b}}$ & $41 \pm 5$ \\
\hline $1.1^{\mathrm{d}}$ & 75 & $4^{\mathrm{b}}$ & $45 \pm 5$ \\
\hline $1.5^{\mathrm{d}}$ & 118 & $4^{\mathrm{b}}$ & $61 \pm 7$ \\
\hline 1.6 & 70 & $4^{\mathrm{b}}$ & $53 \pm 6$ \\
\hline $1.9^{\mathrm{d}}$ & 110 & $4^{b}$ & $80 \pm 10$ \\
\hline $2.5^{\mathrm{e}}$ & 110 & $4^{\mathrm{b}}$ & $100 \pm 10$ \\
\hline $2.8^{\mathrm{d}}$ & 110 & $4^{\mathrm{b}}$ & $100 \pm 10$ \\
\hline
\end{tabular}

a 27 ppmv cyclohexane added as $\mathrm{OH}$ scavenger.

b Estimated value.

c 65 ppmv 1,3-dioxolane added as $\mathrm{OH}$ scavenger.

d 0.6 ppmv 1,3-dioxolane used as $\mathrm{OH}$ tracer.

e 45 ppmv 1,3-dioxolane added as $\mathrm{OH}$ scavenger.

as $\mathrm{OH}$ tracer (see Fig. 2c for example). The tracer decay rate was about $2 \times 10^{-5} \mathrm{~s}^{-1}$ which is nearly the same as the leak rate. This enabled us to estimate the loss of 1,3-dioxolane due to $\mathrm{OH}$ reaction to be less than $1 \times 10^{-5} \mathrm{~s}^{-1}$ from which we could derive an upper limit of the $\mathrm{OH}$ concentration which was found to be $\approx 1 \times 10^{6} \mathrm{~cm}^{-3}$. Therefore, it was concluded that the reactions involving $\mathrm{OH}$ radicals were not significant compared those of $\mathrm{O}_{3}$ reactions under our experimental conditions.

Although experiments were reproducible, additional measurements were performed using the relative method in order to check any systematic errors due to the interferences observed with the ozone UV analyzer as described above. 


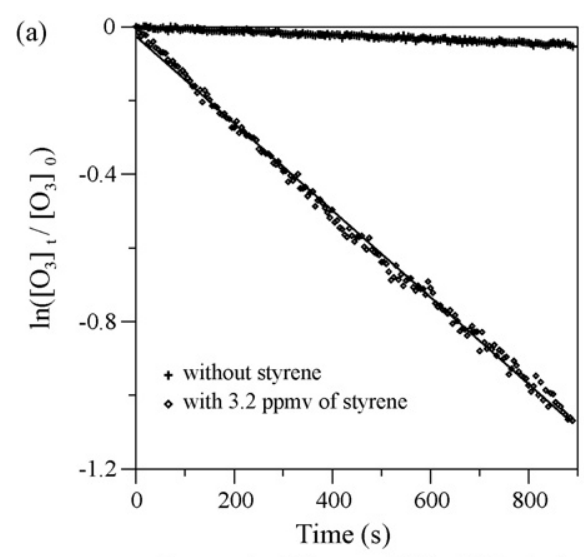

([styrene $]_{0}=3.2 \mathrm{ppmv} ;\left[\mathrm{O}_{3}\right]_{0}=177 \mathrm{ppbv}$ )

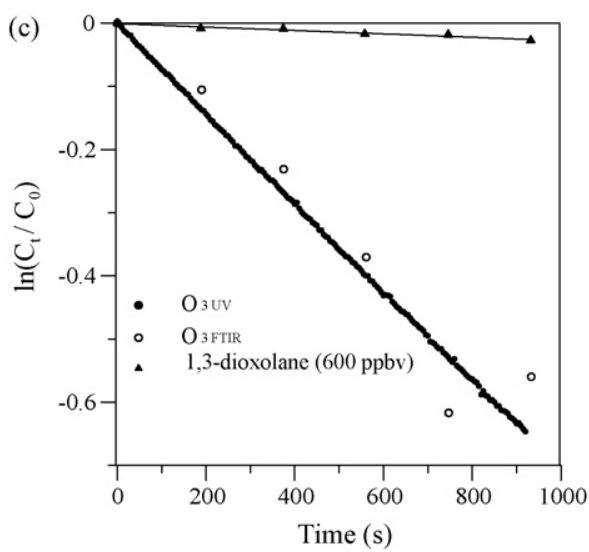

([2-methylstyrene $]_{0}=1.6 \mathrm{ppmv} ;\left[\mathrm{O}_{3}\right]_{0}=140 \mathrm{ppbv}$;

$\left[1,3-\right.$ dioxolane $\left._{0}=600 \mathrm{ppbv}\right)$

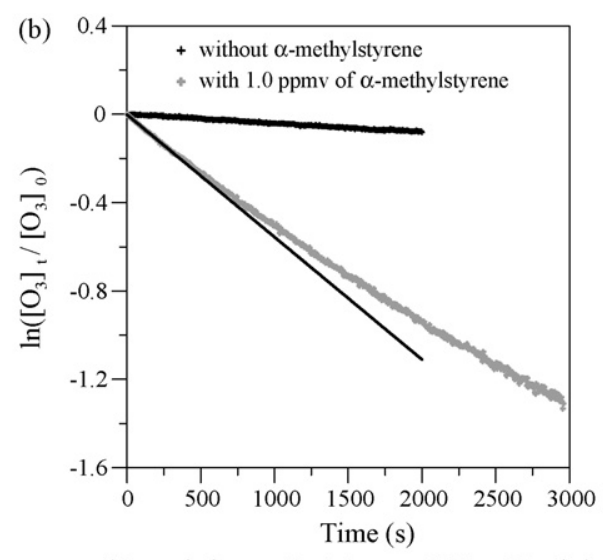

([ $\alpha$-methylstyrene $\left.]_{0}=1.0 \mathrm{ppmv} ;\left[\mathrm{O}_{3}\right]_{0}=91 \mathrm{ppbv}\right)$

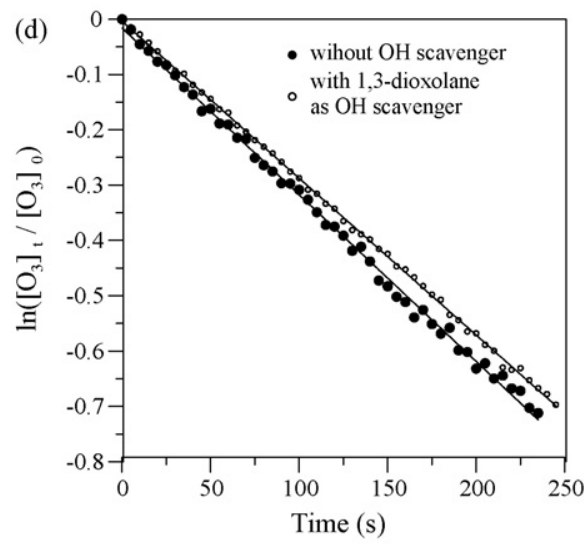

([indene $]_{0}=0.8 \mathrm{ppmv} ;\left[\mathrm{O}_{3}\right]_{0}=47 \mathrm{ppbv}$ or $[\text { indene }]_{0}=0.8$ ppmv; $\left[\mathrm{O}_{3}\right]_{0}=96 \mathrm{ppbv}$ and $[1,3 \text {-dioxolane }]_{0}=44 \mathrm{ppmv}$ )

Fig. 2. (a-d) Kinetics $\mathrm{O}_{3}+$ aromatics (absolute method): Examples of ozone (and 1,3-dioxolane when present) decays vs. reaction time (the lines represent the best fit to the experimental data, see text).

\subsubsection{Relative method}

The relative rate coefficients were determined by comparing the reaction rate of ozone with the aromatics to that with a reference compound:

$\mathrm{O}_{3}+$ aromatic $\rightarrow$ products $\quad\left(k_{\mathrm{ar}}\right)$

$\mathrm{O}_{3}+$ reference $\rightarrow$ products $\quad\left(k_{\mathrm{ref}}\right)$

where $k_{\text {ar }}$ and $k_{\text {ref }}$ are the rate coefficients of $\mathrm{O}_{3}$ reaction with aromatic compounds and reference, respectively. Assuming that the reaction with $\mathrm{O}_{3}$ is the only significant loss process for both aromatic and reference after correction of the concentrations due to the leak and wall losses, $k_{\mathrm{ar}}$ can be derived from the following equation:

$\ln \left(\frac{[\text { Aromatic }]_{0}}{[\text { Aromatic }]_{t}}\right)=\left(\frac{k_{\mathrm{ar}}}{k_{\mathrm{ref}}}\right) \times \ln \left(\frac{[\mathrm{Ref}]_{0}}{[\mathrm{Ref}]_{t}}\right)$

where the subscripts 0 and $t$ indicate concentrations at the beginning of the experiment and at time $t$, respectively.

At least two runs were conducted for each aromatic compound in the presence of $85 \mathrm{ppmv}$ of dibutyl ether to scavenge $\mathrm{OH}$ radicals $\quad\left(k_{\mathrm{dnBE}}=(2.69 \pm 0.22) \times 10^{-11} \mathrm{~cm}^{3}\right.$ molecule ${ }^{-1} \mathrm{~s}^{-1}$ [21]). Propene was chosen as the reference compound for the ozonolysis of styrene, $\alpha$-methylstyrene and 2methylstyrene and propylvinylether and cyclohexene as the references for the ozonolysis of indene. The initial concentrations were in the range 1-4 ppmv for ozone and around 4-5 ppmv for the aromatics and references. The experimental conditions and the results are listed in Table 3.

First, the gas mixture (aromatic, reference and scavenger) was maintained in the chamber without ozone for at least $1 \mathrm{~h}$ in order to quantify the possible loss on the Teflon walls of the chamber. The corresponding rates were found to be close to the leak rate, about $(2 \pm 1) \times 10^{-5} \mathrm{~s}^{-1}$. Then ozone was added and its concentration quantified by FTIR spectroscopy. After correction for the leakage, plots presented in Fig. 4 of experimental data for $\ln \left([\text { Aromatic }]_{0} /[\text { Aromatic }]_{t}\right)$ versus $\ln \left([\operatorname{Ref}]_{0} /[\operatorname{Ref}]_{t}\right)$ exhibit straight lines and the slopes are equal to $k_{\mathrm{ar}} / k_{\text {ref }}$ and listed in Table 3. Using a rate coefficient of $(0.94 \pm 0.06) \times 10^{-17} \mathrm{~cm}^{3}$ molecule ${ }^{-1} \mathrm{~s}^{-1}$ for the reaction $\mathrm{O}_{3}+$ propene [22], $(2.34 \pm 0.48) \times 10^{-16} \mathrm{~cm}^{3}$ molecule ${ }^{-1} \mathrm{~s}^{-1}$ 

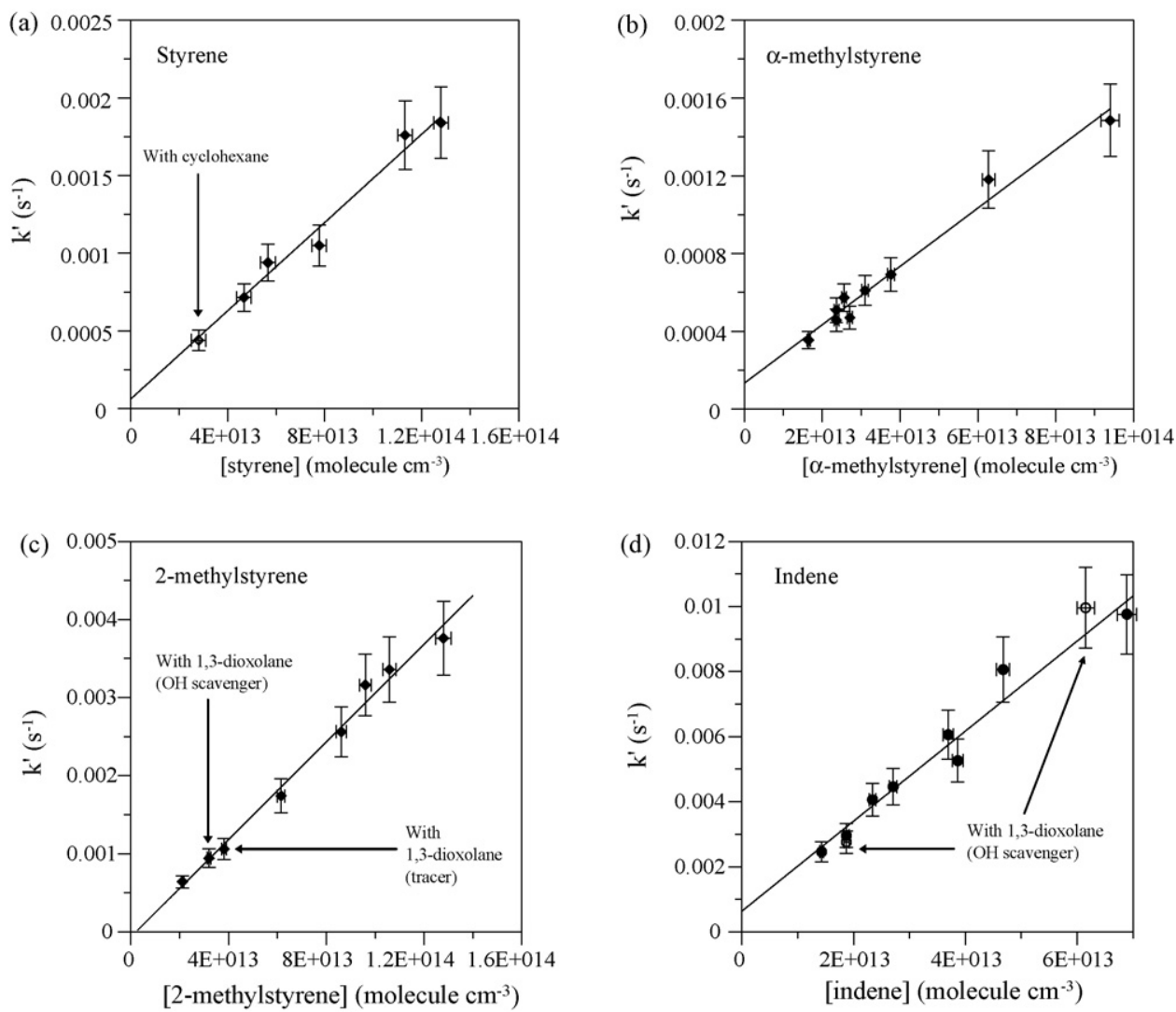

Fig. 3. (a-d) Kinetics $\mathrm{O}_{3}+$ aromatics (absolute method): plots of the ozone pseudo-first-order rate constants $k^{\prime}$ vs. the concentration of the aromatic compound. The slopes are equal to the ozonolysis rate constants $k_{\text {ar }}$ (Eq. (5), see text).

for the reaction $\mathrm{O}_{3}+$ propylvinyl ether [23] and $(0.8 \pm 0.2) \times 10^{-16} \mathrm{~cm}^{3}$ molecule ${ }^{-1} \mathrm{~s}^{-1}$ for the reaction $\mathrm{O}_{3}+$ cyclohexene [24], the resulting values of $k_{\mathrm{ar}}$ and are listed in Table 3, are in good agreement with those obtained by the absolute method (see Table 4).

\subsubsection{Discussion}

The average rate coefficients for the reactions of the studied aromatics and $\mathrm{O}_{3}$ at $295 \pm 3 \mathrm{~K}$ and atmospheric pressure are (in $10^{-17} \mathrm{~cm}^{3}$ molecule $\left.\mathrm{s}^{-1}\right):(1.5 \pm 0.3),(1.8 \pm 0.4),(3.1 \pm 0.6)$ and $(16 \pm 4)$ for styrene, $\alpha$-methylstyrene, 2-methylstyrene and

Table 3

Experimental conditions and results for the relative kinetic studies of $\mathrm{O}_{3}$ reactions with aromatics at $295 \pm 3 \mathrm{~K}$ and atmospheric pressure $\left(k_{\mathrm{ar}}\right.$ is given in $10^{-17} \mathrm{~cm}^{3}$ molecule ${ }^{-1} \mathrm{~s}^{-1}$ )

\begin{tabular}{|c|c|c|c|c|c|c|}
\hline \multicolumn{2}{|c|}{$[\text { Aromatic }]_{0}(\mathrm{ppmv})$} & \multicolumn{2}{|l|}{$[\operatorname{Ref}]_{0}(\mathrm{ppmv})$} & {$\left[\mathrm{O}_{3}\right]_{0}(\mathrm{ppmv})^{\mathrm{a}}$} & $k_{\mathrm{ar}} / k_{\mathrm{ref}}$ & $k_{\mathrm{ar}}^{\mathrm{b}}$ \\
\hline $4.3^{\mathrm{c}}$ & & $4.1^{\mathrm{d}}$ & 1.5 & & $1.6 \pm 0.1$ & $1.5 \pm 0.3$ \\
\hline $5.3^{\mathrm{c}}$ & & $5.2^{\mathrm{d}}$ & 4 & & $1.6 \pm 0.1$ & \\
\hline $5.0^{\mathrm{e}}$ & & $5.1^{\mathrm{d}}$ & 4 & & $2.2 \pm 0.2$ & \\
\hline $5.1^{\mathrm{f}}$ & & $5.2^{\mathrm{d}}$ & 4 & & $3.4 \pm 0.2$ & \\
\hline $5.1^{\mathrm{f}}$ & & $4.9^{\mathrm{d}}$ & 4 & & $3.2 \pm 0.3$ & $3.1 \pm 0.6$ \\
\hline Indene & $\mathrm{PVE}^{\mathrm{g}}$ & $\mathrm{CYCLO}^{\mathrm{g}}$ & {$\left[\mathrm{O}_{3}\right]_{0}(\mathrm{ppmv})^{\mathrm{a}}$} & PVE & CYCLO & $k_{\mathrm{ar}}^{\mathrm{b}}$ \\
\hline 6.0 & 5.9 & 6.0 & $0.7(+1.3+2)$ & $0.83 \pm 0.02$ & $2.20 \pm 0.06$ & $1.8 \pm 0.5$ \\
\hline 6.0 & 5.9 & 6.0 & $0.7(+1.3+2.2+3)$ & $0.80 \pm 0.02$ & $2.04 \pm 0.02$ & $1.7 \pm 0.4$ \\
\hline
\end{tabular}

${ }^{\mathrm{a}}\left[\mathrm{O}_{3}\right]_{0}$ is the maximum $\mathrm{O}_{3}$ concentration given by FTIR spectroscopy at the introduction of $\mathrm{O}_{3}$.

\footnotetext{
b $k_{\text {propene }}=(0.94 \pm 0.06) \times 10^{-17} \mathrm{~cm}^{3}$ molecule ${ }^{-1} \mathrm{~s}^{-1}$

[22]; $\quad k_{\mathrm{PVE}}=(2.34 \pm 0.48) \times 10^{-16} \mathrm{~cm}^{3}$ molecule $^{-1} \mathrm{~s}^{-1}$

[23]; $\quad k_{\mathrm{CYCLO}}=(0.8 \pm 0.2) \times$

$10^{-16} \mathrm{~cm}^{3}$ molecule ${ }^{-1} \mathrm{~s}^{-1}[24]$.

${ }^{\mathrm{c}}$ Styrene.

${ }^{\mathrm{d}}$ Propene.

e $\alpha$-Methylstyrene.

f 2-Methylstyrene.

g PVE is propylvinyl ether and CYCLO is cyclohexene.
} 

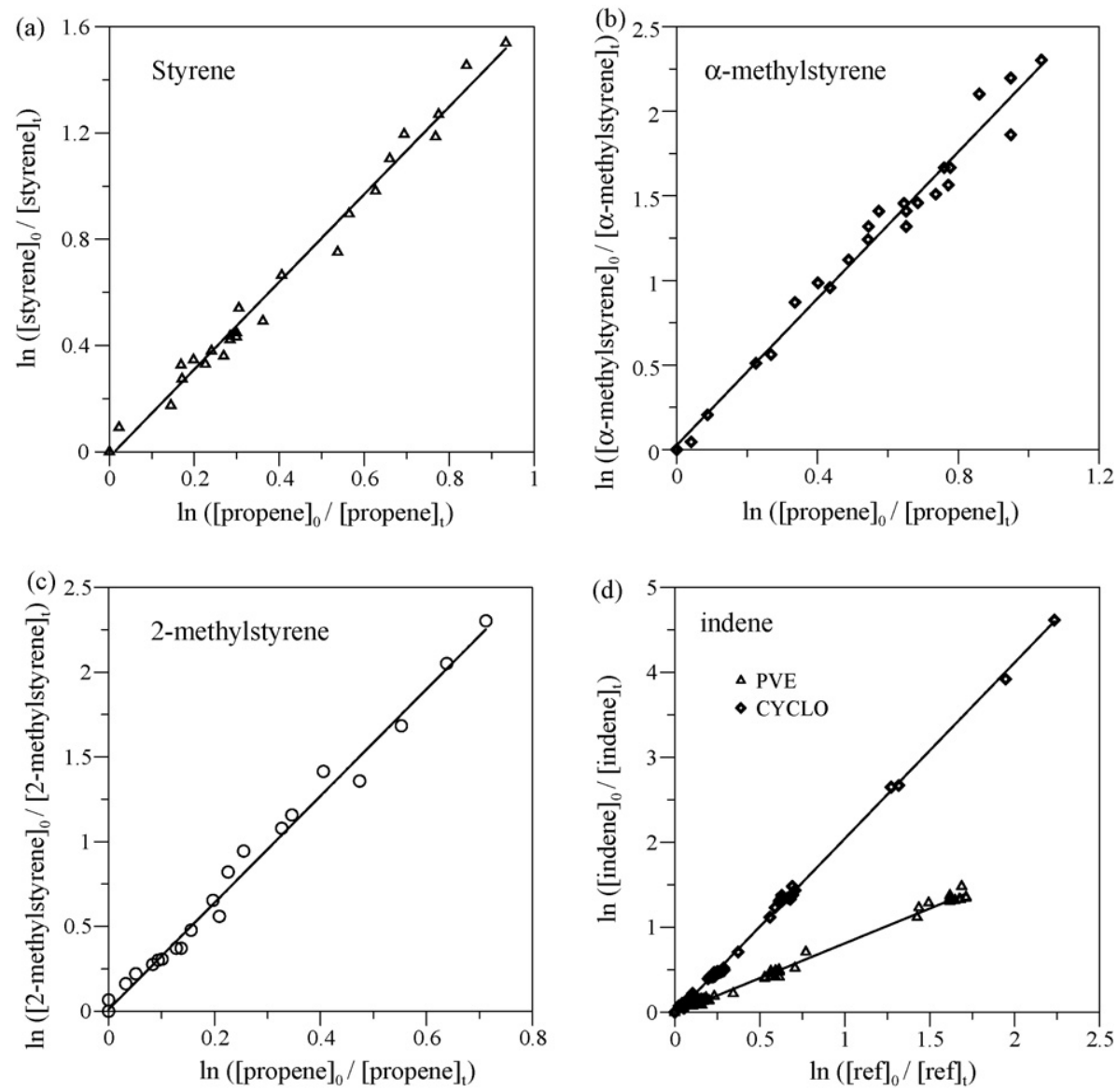

Fig. 4. Kinetics $\mathrm{O}_{3}+$ aromatics (relative method): plots of $\ln \left([\text { Aromatic }]_{0} /[\text { Aromatic }]_{t}\right)$ vs. $\ln \left([\operatorname{Ref}]_{0} /[\operatorname{Ref}]_{t}\right.$ ) using FTIR. According to Eq. (6), the slopes are equal to $k_{\text {ar }} / k_{\text {ref }}$ (PVE, propyl vinyl ether; CYCLO, cyclohexene, see text).

Table 4

Rate constants for the ozonolysis of styrene, $\alpha$-methylstyrene, 2-methylstyrene and indene obtained by absolute and relative methods at $295 \pm 3 \mathrm{~K}$ and atmospheric pressure

\begin{tabular}{|c|c|c|}
\hline Aromatic compound & Rate constant $k_{\text {ar }}\left(10^{-17} \mathrm{~cm}^{3}\right.$ molecule $\left.{ }^{-1} \mathrm{~s}^{-1}\right)$ & Reference \\
\hline Styrene & $\begin{array}{l}1.4 \pm 0.3 \\
1.5 \pm 0.3 \\
2.16 \pm 0.46 \\
1.71 \pm 0.18 \\
7.9\end{array}$ & $\begin{array}{l}\text { This work, absolute method } \\
\text { This work, relative method } \\
\text { [5] } \\
{[6]} \\
{[7]}\end{array}$ \\
\hline$\alpha$-Methylstyrene & $\begin{array}{l}1.5 \pm 0.3 \\
2.0 \pm 0.4\end{array}$ & $\begin{array}{l}\text { This work, absolute method } \\
\text { This work, relative method }\end{array}$ \\
\hline 2-Methylstyrene & $\begin{array}{l}3.1 \pm 0.5 \\
3.1 \pm 0.6\end{array}$ & $\begin{array}{l}\text { This work, absolute method } \\
\text { This work, relative method }\end{array}$ \\
\hline Indene & $\begin{array}{l}15 \pm 3 \\
18 \pm 5 \\
17 \pm 5\end{array}$ & $\begin{array}{l}\text { This work, absolute method } \\
\text { This work, relative method } \\
\text { [8] }\end{array}$ \\
\hline
\end{tabular}


indene, respectively. This work provides the first measurement of the ozone reaction rate coefficients with 2-methylstyrene and $\alpha$-methylstyrene. For styrene, our measured value is in good agreement with that reported earlier by Tuazon et al. [6] but slightly lower than that of Atkinson et al. [5]. However, the agreement can be regarded reasonable when the uncertainties in both measurements are considered (see Table 4). The rate coefficient value reported by Zhang et al. [7] is almost four times higher than determined in this work. However, the measurement of Zhang et al. [7] represents the result of a single experiment. Regarding the rate coefficient of ozone with indene, our data is in good agreement with the value reported by Kwok et al. [8].

The $\mathrm{O}_{3}$ reactions with alkyl benzenes and indane are quite slow (e.g. $k\left(\mathrm{O}_{3}+\right.$ toluene $)<10^{-21} \mathrm{~cm}^{3}$ molecule ${ }^{-1} \mathrm{~s}^{-1}$, $k\left(\mathrm{O}_{3}+1,3,5\right.$-trimethylbenzene $)<10^{-20} \mathrm{~cm}^{3}$ molecule ${ }^{-1} \mathrm{~s}^{-1}$ and $k\left(\mathrm{O}_{3}+\right.$ indane $)<3 \times 10^{-19} \mathrm{~cm}^{3}$ molecule $\left.\mathrm{s}^{-1} \mathrm{~s}^{-1}\right) \quad$ [25] compared to alkene benzenes and indene studied here. On the other hand, the reaction rate coefficients for each of the aromatic compound investigated in this work are close to those of the alkene (in $\mathrm{cm}^{3}$ molecule ${ }^{-1} \mathrm{~s}^{-1}$ ): $k_{\text {styrene }} \sim k_{\text {propene }}$ $\left(1.0 \times 10^{-17}\right), \quad k_{\alpha \text {-methylstyrene }} \sim k_{\text {isobutene }}\left(1.0 \times 10^{-17}\right)$ and $k_{\text {indene }} \sim k_{\text {cis-pent-2-ene or } c i s-b u t-2 \text {-ene }}\left(1.3 \times 10^{-16}\right)[24,26]$. This observation indicates that the reaction of ozone with the unsaturated aromatic compounds studied here occurs essentially through the addition of $\mathrm{O}_{3}$ to the double bond of the alkene groups. The phenyl group might be expected to slow down the reaction by electron-attractive mesomeric effect, but it does not seem to have much influence for the investigated aromatics. A methyl group on $\alpha$-position seems to have a little or no effect for $\mathrm{O}_{3}$ addition on the alkene bond since $k_{\alpha-\text { methylstyrene }} \sim k_{\text {styrene }}$ similarly to $k_{\text {isobutene }} \sim k_{\text {propene. }}$. The reaction rate coefficient of ozone with 2-methylstyrene is a factor 2 higher than that with styrene. The reason might be due to the electron-donating inductive effect of the orthomethyl group. This does not exclude that the steric effects may also be important in these reactions. Indene is much more reactive towards ozone than styrene and the other two methyl styrenes ( $\alpha$-methyl and 2-methyl) studied here. However, indene is less reactive than cyclopentene, indicating that the phenyl group has an effect on the reactivity towards $\mathrm{O}_{3} \quad\left(k_{\text {cyclopentene }}=5.7 \times 10^{-16} \mathrm{~cm}^{3}\right.$ molecule $^{-1} \mathrm{~s}^{-1}$ [27]).

\section{Atmospheric implications}

The tropospheric lifetimes of the investigated aromatics corresponding to each loss pathway $\left(\tau_{v}=1 / J, \tau_{\mathrm{OH}}=1 /\left(k_{\mathrm{OH}}[\mathrm{OH}]\right)\right.$, $\tau_{\mathrm{O}_{3}}=1 /\left(k_{\mathrm{O}_{3}}\left[\mathrm{O}_{3}\right]\right)$ and $\tau_{\mathrm{NO}_{3}}=1 /\left(k_{\mathrm{NO}_{3}}\left[\mathrm{NO}_{3}\right]\right)$ were estimated based on the parameters measured in this study for the photolysis and ozonolysis and the reported values in the literature for the reactions of $\mathrm{OH}$ and $\mathrm{NO}_{3}$ radicals with the aromatics. The average concentrations of $\mathrm{OH}, \mathrm{O}_{3}$ and $\mathrm{NO}_{3}$ are taken as $2 \times 10^{6} \mathrm{~cm}^{-3}$ [28], $7 \times 10^{11}$ molecule $\mathrm{cm}^{-3}$ [29] and $5 \times 10^{8} \mathrm{~cm}^{-3}$ [30], respectively. The rate coefficients values used for the cal- culations are (in $\mathrm{cm}^{3}$ molecule $\left.\mathrm{e}^{-1} \mathrm{~s}^{-1}\right)(5.8 \pm 0.1) \times 10^{-11}$ [10], $(5.3 \pm 0.6) \times 10^{-11}$ [9] and $(7.8 \pm 0.3) \times 10^{-11}$ [8] for the reactions of $\mathrm{OH}$ with styrene, $\alpha$-methylstyrene and indene, respectively. They are $(1.51 \pm 0.04) \times 10^{-12}[10]$ and $(4.08 \pm 0.26) \times 10^{-12}[8]$ for the reactions of $\mathrm{NO}_{3}$ with styrene and indene, respectively. The calculated lifetimes are in the ranges $2-3 \mathrm{~h},<1 \mathrm{~h}, 2 \mathrm{~h}-1$ day and $>1-10$ days for the $\mathrm{OH}, \mathrm{NO}_{3}$, $\mathrm{O}_{3}$ reactions and for the photolysis, respectively. This clearly shows that reactions with $\mathrm{OH}, \mathrm{NO}_{3}$ and $\mathrm{O}_{3}$ are all important as atmospheric loss processes for the studied aromatics in the gas phase. Hence, products studies of these three processes are of crucial importance in order to assess the real impact of this type of species on air quality.

\section{Acknowledgments}

The authors wish to acknowledge the French Ministry of Environment and ADEME through Primequal programme and Eurochamp EU project for support.

\section{References}

[1] P.F. Nelson, S.M. Quigley, M.Y. Smith, Sources of atmospheric hydrocarbons in Sydney: A quantitative determination using a source reconciliation technique, Atmos. Environ. 17 (1983) 439-449.

[2] C.W. Spicer, E.G. Chapman, B.J. Finlayson-Pitts, R.A. Plastridge, J.M. Hubbe, J.D. Fast, C.M. Berkowitz, Unexpectedly high concentrations of molecular chlorine in coastal air, Nature 394 (1998) 353-356.

[3] H. Rothweiler, P.A. Waeger, C. Schlatter, Volatile organic compounds and some very volatile organic compounds in new and recently renovated buildings in Switzerland, Atmos. Environ. 26A (1992) 2219-2225.

[4] R. Derwent, M.E. Jenkin, S.M. Saunders, Photochemical ozone creation potentials for a large number of reactive hydrocarbons under European conditions, Atmos. Environ. 30 (1996) 181-199.

[5] R. Atkinson, S.M. Aschmann, D.R. Fitz, A.M. Winer, J.N. Pitts, Rate constants for the gas-phase reactions of $\mathrm{O}_{3}$ with selected organics at $296 \mathrm{~K}$, Int. J. Chem. Kinet. 14 (1982) 13-18.

[6] E.C. Tuazon, J. Arey, R. Atkinson, S.M. Aschmann, Gas-phase reactions of 2-vinylpyridine and styrene with $\mathrm{OH}$ and $\mathrm{NO}_{3}$ radicals and $\mathrm{O}_{3}$, Environ. Sci. Technol. 27 (1993) 1832-1841.

[7] J. Zhang, W.E. Wilson, P.J. Lioy, Indoor air chemistry: formation of organic acids and aldehydes, Environ. Sci. Technol. 28 (1994) 1975-1982.

[8] E.S.C. Kwok, R. Atkinson, J. Arey, Kinetics of the gas-phase reactions of indane, indene, fluorine, and 9,10-dihydroanthracene with $\mathrm{OH}$ radicals, $\mathrm{NO}_{3}$ radicals, and $\mathrm{O}_{3}$, Int. J. Chem. Kinet. 29 (1997) 299-309.

[9] C.A. Bignozzi, A. Maldotti, C. Chiorboli, C. Bartocci, V. Carassiti, Kinetics and mechanism of reactions between aromatic olefins and hydroxyl radicals, Int. J. Chem. Kinet. 13 (1981) 1235-1242.

[10] R. Atkinson, S.M. Aschmann, Kinetics of the reactions of acenaphthene and acenaphthylene and structurally-related aromatic compounds with $\mathrm{OH}$ and $\mathrm{NO}_{3}$ radicals, $\mathrm{N}_{2} \mathrm{O}_{5}$ and $\mathrm{O}_{3}$ at $296 \pm 2 \mathrm{~K}$, Int. J. Chem. Kinet. 20 (1988) 513-539.

[11] Y. Mu, A. Mellouki, The near UV-absorption cross-sections for several ketones, J. Photochem. Photobiol. A: Chem. 134 (2000) 31-36.

[12] P. Neeb, G.K. Moortgat, Formation of $\mathrm{OH}$ radicals in the gas-phase reaction of propene, isobutene, and isoprene with $\mathrm{O}_{3}$ : yields and mechanistic implications, J. Phys. Chem. A 103 (1999) 9003-9012.

[13] A.R.D. Rickard, M.C.D. Johnson, G. Martson, OH yields in the gas-phase reactions of ozone with alkenes, J. Phys. Chem. A 103 (1999) 76567664.

[14] T. Etzkorn, B. Klotz, S. Sorensen, S. Patroescu, I. Barnes, K.H. Becker, U. Platt, Gas-phase absorption cross-sections of 24 monocyclic aromatic 
hydrocarbons in the UV and IR spectral ranges, Atmos. Environ. 33 (1999) 525-540.

[15] G. Thiault, A. Mellouki, G. Le Bras, A. Chakir, N. Sokolowsky-Gomez, D. Daumont, UV-absorption cross-sections of benzaldehyde, ortho-, meta, and para-tolualdehyde, J. Photochem. Photobiol. A: Chem. 162 (2-3) (2004) 273-281.

[16] B.J. Finlayson-Pitts, J.N. Pitts, Atmospheric Chemistry, Wiley, New York, 1986.

[17] R.D. Martinez, A.A. Buitrago, N.W. Howell, C.H. Hearn, J.A. Joens, The near UV absorption spectra of several aliphatic aldehydes and ketones, Atmos. Environ. 26 (1992) 785.

[18] B.J. Finlayson-Pitts, J.N. Pitts, Chemistry of the Upper and Lower Atmosphere, Academic Press, California, 1999.

[19] F. Kramp, S.E. Paulson, On the uncertainties in the rate coefficients for $\mathrm{OH}$ reactions with hydrocarbons, and the rate coefficients of the 1,3,5trimethylbenzene and $m$-xylene reactions with $\mathrm{OH}$ radicals in the gas phase, J. Phys. Chem. A 102 (1998) 2685-2690 (and references therein).

[20] S. Le Calvé, A. Mellouki, G. Le Bras, Kinetics studies of OH reactions with propylal, butylal and 1,3-dioxolane, Phys. Chem. Chem. Phys. 4 (2002) $5622-5626$.

[21] A. Mellouki, S. Téton, G. Le Bras, Kinetics of OH radical reactions with a series of ethers, Int. J. Chem. Kinet. 27 (1995) 791-805.

[22] R. Atkinson, D.L. Baulch, R.A. Cox, J.N. Crowley, R.F. Hampson Jr., J.A. Kerr, M.J. Rossi, J. Troe, Summary of Evaluated Kinetic and Photochemical Data for Atmospheric Chemistry, IUPAC Subcommittee on Gas Kinetic
Data Evaluation for Atmospheric ChemistryWeb Version December 2001, 2001, pp. 1-56 http://www.iupac-kinetic.ch.cam.ac.uk/index.html.

[23] S. Zhou, I. Barnes, T. Zhu, I. Bejan, T. Benter, Kinetic study of the gasphase reactions of $\mathrm{OH}$ and $\mathrm{NO}_{3}$ radicals and $\mathrm{O}_{3}$ with selected vinyl ethers, J. Phys. Chem. A 110 (2006) 7386-7392.

[24] J.G. Calvert, R. Atkinson, J.A. Kerr, S. Madronich, G.K. Moortgat, T.J. Wallington, G. Yarwood, The Mechanisms of Atmospheric Oxidation of the Alkenes, Oxford University Press, 2000.

[25] J.G. Calvert, R. Atkinson, K.H. Becker, R.M. Kamens, J.H. Seinfeld, T.J. Wallington, G. Yarwood, The Mechanisms of Atmospheric Oxidation of Aromatic Hydrocarbons, Oxford University Press, 2002.

[26] R. Atkinson, W.P.L. Carter, Kinetics and mechanisms of the gas-phase reactions of ozone with organic compounds under atmospheric conditions, Chem. Rev. 84 (1984) 437-470.

[27] R. Atkinson, Gas-phase tropospheric chemistry of volatile organic compounds: 1. Alkanes and alkenes, J. Phys. Chem. Ref. Data 26 (1997) 215-290.

[28] R. Hein, P.J. Crutzen, M. Heimann, An inverse modeling approach to investigate the global atmospheric methane cycle, Glob. Biogeochem. Cyc. 11 (1997) 43-76.

[29] J.A. Logan, Tropospheric ozone-seasonal behaviour, trends, and anthropogenic influence, J. Geophys. Res. 90 (1985) 10363-10482.

[30] R. Atkinson, Kinetics and mechanisms of the gas phase reactions of the NO3 radical with organic compounds, Phys. Chem. Ref. Data 20 (1991) 459-507. 